\title{
PEMETAAN DATA DAN INFORMASI PENYUSUNAN PERENCANAAN PEMBANGUN DESA DI KECAMATAN TAMBANG KABUPATEN KAMPAR
}

\author{
Aguswan, Sulaiman Zuhdi \\ Universitas Lancang Kuning \\ e-mail: aguswan72@unilak.ac.id
}

\begin{abstract}
Mapping of data and information on the preparation of village development planning dikecamatan Tambang Kabupaten Kampar. The preparation of village development planning is very important to be carried out by the village head and its equipment. The objectives of the village planning arranged for the village development plan can be discussed in the village development consultation forum. In this Forum the village development plan is matured, so it becomes the Village Development Plan. The preparation of village development planning can not be carried out properly, without complete data and information either in the implementation of village government, organization and governance of village administration, village finance, village profile and other information related to governance and community empowerment. The three villages that were used as research mapping object in Kampar sub-district Tambang were Tarai build village, Rimbo Panjang village and Tambang village. Village development planning in the three sample villages appears to be underdeveloped by complete data and information, and this has a major impact on the Village Mid Term Development Plan (RPJMDesa) and the Government-Village Action Plan (RKP -Desa) which guides development implementation in the countryside.
\end{abstract}

Keywords: Mapping, data and planning information, village development

\begin{abstract}
Abstrak
Pemetaan data dan informasi penyusunan perencanaan pembangunan desa dikecamatan Tambang Kabupaten Kampar. Penyusunan perencanaan pembangunan Desa sangat penting untuk dilaksanakan oleh kepala Desa dan perangkatnya. Tujuan dari Perencanaan desa yang tersusun agar rancangan pembangunan desa dapat di bahas pada forum musyawarah pembangunan Desa. Dalam Forum inilah rencana pembangunan desa dimatangkan, sehingga menjadi Rencana Pembangunan Desa. Penyusunan perencanaan pembangunan desa tidak bisa dilaksanakan dengan baik, tanpa adanya data dan informasi lengkap baik dalam penyelenggaraan pemerintahan Desa, organisasi dan tata laksana pemerintahan desa, keuangan desa, profil desa dan informasi lain terkait dengan penyelenggaraan pemerintahan dan pemberdayaan masyarakat. Tiga desa yang dijadikan obyek pemetaan penelitian di kecamatan Tambang Kabupaten Kampar yaitu Desa Tarai bangun, Desa Rimbo Panjang dan Desa Tambang. Perencanaan pembangunan desa ditiga desa sampel terlihat masih kurang di dukung oleh data dan informasi yang lengkap, dan hal ini sangat mempengaruhi pada proses Penyusunan Rencana Pembangunan jangka Menengah Desa (RPJMDesa) dan Rencana kerja Pemerintah - Desa (RKP -Desa) yang menjadi pedoman pelaksanaan pembangunan diperdesaan.
\end{abstract}

Kata Kunci : Pemetaan, data dan informasi perencanaan, pembangunan desa 


\section{PENDAHULUAN}

Pembangunan secara sederhana di artikan sebagai perubahan tingkat kesejahteraan secara sengaja dan terukur. Agar perubahan tingkat kesejahteraan dapat dilakukan secara terukur, diperlukan perencanaan. Dalam arti luas perencanaan merupakan upaya manusia meminimalkan ketidak pastian. Dan perencanaan ideal adalah langkah - langkah yang dilakukan manusia agar kepastian semakin dekat dalam kehidupan manusia. Perencanaan dalam arti sempit sesungguhnya merupakan derivat dari kemampuan Foresight yaitu kemampuan mengukur (Meansuring).

Secara defenitif, dalam UU Sistem Perencanaan Pembangunan Nasional (SPPN), perencanaan adalah proses menentukan tindakan masa depan yang tepat melalui urutan pilihan dengan memperhitungkan sumber daya yang tersedia. Sistem perencanaan pembangunan nasional adalah satu kesatuan tata cara perencanaan pembangunan untuk menghasilkan rencana pembangunan jangka panjang, jangka menengah dan tahunan yang dilaksanakan oleh unsur penyelenggara negara dan masyarakat di tingkat pusat dan Daerah.

Dokumen rencanan pembangunan desa sebagai dasar penyusunan anggaran pendapatan dan belanja desa. Perencanaan pembangunan desa diselenggarakan dengan mengikutsertakan masyarakat desa melalui musyawarah rencana pembangunan desa menetapkan prioritas, program, kegiatan, dan kebutuhan pembangunan desa yang didanai oleh APBDes, dan atau anggaran pendapatan dan belanja Daerah kabupaten/kota berdasarkan penilaian terhadap kebutuhan masyarakat desa.

Perencanaan desa di susun oleh kepala desa dan perangkatnya. Kepala Desa bertanggung jawab dalam penyusunan perencanaan RPJM- Desa dan RKP- Desa. Setelah kepala Desa membuat rancangan pembangunan desa, rancangan ini dibawa dalam forum Musyawarah Rencana Pembangunan Desa (Musrembang Desa). Dalam forum inilah rencana pembangunan desa di matangkan menjadi rencana pembangunan Desa.

Pengumpulan Data dan informasi merupakan langkah awal dalam penyusunan perencanan pembangunan desa yang selanjutny akan dibahas pada Musrembang desa. Oleh karena itu perlu dilakukan pemetaan sejauh mana data dan informasi telah tersedia dan dapat membantu petugas perencana desa dalam menetapkan perioritas pembangunan desa yang baik yang didanai dari alokasi dana desa (ADD)/ APBD kabupaten/kota dan atau swadaya.

Desa tarai bangun, desa Rimbo panjang dan Desa Tambang adalah tiga desa dari 21 Desa yang berada dalam wilayah kecamatan tambang Kabupaten Kampar Provinsi Riau. Pentingnya dilakukan Pemetaan data dan Informasi dalam penyusuan perencanaan pembangunan Desa adalah untuk membantu Pemerintah desa dalam merumuskan dan menetapkan rencana pembangunan desa yang akan dijadikan sebagai keputusan kepala Desa. Kebutuhan data dan informasi dalam perencanaan desa diperlukan berupa: Profil desa, penyelenggaraan pemerintahan desa, organisasi dan tatalaksana desa, keungan desa dan informasi pemerintahan dan pemberdayaan masyarakat.

Kelengkapan data dan informasi sebagai mana yang disebutkan di atas,

dapat membantu Pemerintahan desa dalam menyiapkan dokumen perencanaan pembangunan desa yang dibahas pada musyawarah rencana pembangunan desa (musrembangdes).

Pembangunan secara sederhana di artikan sebagai suatu perubahan tingkat kesejahteraan secara sengaja dan terukur. Agar perubahan tingkat kesejahteraan dapat dilakukan secara terukur diperlukan perencanaan. UU Nomor 25 tahun 2004 tentan Sistem perencanaan pembangunan Nasional (selanjutnya di singkat UU SPN) saat ini. UU tersebut menjadi landasan formal aktivitas lembaga perencanaan pembangunan nasional, yaitu Badan Perencanaan Pembangunan Nasional (Bapppenas) dalam melakukan melakukan penyusunan rencana pembangunan nasional.

Ryant Nugroho, 2011, memberikan makna perencanaan dalam arti yang luas dan sempit. Dalam arti luas perencanaan merupakan upaya manusia meminimalkan ketidak pastian. Dan perencanaan ideal adalah langkah - langkah yang dilakukan manusia agar kepastian semakin dekat dalam kehidupan 
manusia. Kemudian perencanaan dalam arti sempit, sesungguhnya drivat dari kemampuan Foresight itu. Yaitu kemampuan mengukur (Measuring). Inti perencanaan yang ideal sesungguhnya adalah mengukur. Persoalannya tidak semua "sesuatu "itu bersifat materi, sehingga sifatnya "tersembunyi", sehingga sulit di ukur. Di sinilah sesungghunya tugas perencana yaitu mendefenisikan "sesuatu yang tersembunyi" menjadi terukur, sehingga menjadi nyata.Sebagai contoh paling sederhana mendefeniskan "bahagia".

Bahagia barang kali sulit di ukur dibandingkan dengan "sejahtera". Inilah tugas perencana. Bagaimana perencana menuntaskan tugasnya.

Riyant Nugroho, 2011:3 menyebutkan perencanaan setidaknya delapan jenis yaitu :

1. Perencanaan menurut jangka waktu.

2. Perencanaan menurut sifat dorongannya

3. Perencanaan menurut alokasi sumber daya.

4. Perencanaan menurut tingkat keluwesan.

5. Perencanaan menurut system ekonomi.

6. Perencanaan menurut arus informasi

7. Perencanaan menurut dimensi pendekatan

8. Perencanaan menurut lingkaran aktivitas pembangunan.

Undang - Undang Nomor 25 tahun 2004, tentang sistem perencanaan pembangunan Nasional merupakan landasan hukum di Bidang Perencanaan pembangunan. Peraturan ini merupakan satu kesatuan tata cara perencanaan pembangunan untuk menghasilkan rencana pembangunan jangka panjang, jangka menegah, dan tahunan yang dilaksanakan oleh unsur penyelenggara pemerintahan di pusat dan daerah dengan melibatkan masyarakat.

Selanjutnya Peraturan Pemerintah No.08 tahun 2008, mengatur tahapan, tata cara penyusunan, pengendalian dan evaluasi pelaksanaan rencana pembangunan Daerah. Peraturan ini dilaksanakan melalui Peraturan Menteri No.54 tahun 2010 yang mengamanatkan bahwa perencanaan daerah antara lain: Rencana Pembangunan jangka Panjang daerah (RPJPD), Rencana Pembangunan jangka Menengah Deerah (RPJMD, dan Rencana Strategis (RESTRA) dirumuskan secara transparan, responsif, efisien, efektif, akuntabel, partisipatif, terukur, berkeadilan, dan berwawasan lingkungan.

Perencanaan daerah merupakan usaha yang sistematis dari berbagai pelaku (aktor), baik umum (publik) atau pemerintah, swasta maupun kelompok masyarakat lainnya pada tingkatan yang berbeda untuk menghadapi saling ketergantungan dan keterkaitan aspek - aspek fisik, sosial, ekonomi dan aspek aspek lingkungan lainnya dengan cara :

a. Secara terus menerus menganlisis kondisi dan pelaksanaan pembangunan daerah.

b. Merumuskan tujuan - tujuan dan kebijakan - kebijakan pembangunan daerah.

c. Menyusun konsep - konsep strategi bagi pemecahan masalah (solusi).

d. Melaksanakannya dengann menggunakan sumber daya yang tersedia, sehingga peluang - peluang baru untuk meningkatkan kesejahteraan masyarakat daerah dapat ditangkap secara berkelanjutan. (Hanif Nurcholis, 2009:9)

Selanjutnya Hanif Nurcholis, menyebutkan bahwa tahapan pembuatan perencanaan kabupaten dengan tahapan berikut:

a. Pemahaman Daerah ( profil / potret).

b. Permusan kebijakan (visi dan misi, tujuan - tujuan, arahan pembangunan, strategi umum, prioritas pembangunan daerah)

c. Permusan dan penetapan program atau rencana tindak sebagai

pedoman pelaksanaan pembangunan daerah.

d. Monitoring dan evaluasi. 
Berdasarkan kerangka hukum yang ada perencanaan pembangunan pada semua tingkatan pemerintah harus menggunakan pendekatan partisipatif. Perencanaan partisipastif menggunakan pendekatan dua arah: dari atas kebawah (Top Down) dan dari bawah ke atas (Bottom up).suatu forum yang dipakai untuk menyelenggarakan perencanaan partisipasi dikenal dengan istilah teknis Musrembang (musyawarah perencanaan pembangunan). Musrembang di mulai dari satuan pemerintahan paling bawah yaitu tingkat Desa / kelurahan kemudian secara hirarki keatas yaitu tingkat kecamatan, tingkat kabupaten/kota, provinsi dan terakhir tingkat pusat.

Untuk menghasilkan dokumen perencanaan partisipatif, pemerintah Kabupaten kota perlu melakukan langkah - langkah yang terencana, terarah, daan terfokus. Bappeda sebagai dapur perencanaan pembangunan Pemerintah daerah merancang langkah - langkah kegiatan untuk menghsilkan dokumen tersebut. Langkah - langkah kegiatan tersebut mulai dari tahap persiapan, penyiapan bahan, penentuan jadwal, fasilitasi untuk pembahasan, formulasi, finalisasi dan proses legislasi. Musrembang Dikabupaten/ Kota dapat dikelompokan dalam tiga jenis :

1. Musrembang Desa/ kelurahan (dilaksanakan pada bulan januari )

2. Musrembang kecamatan (dilaksanakan pada bulan pebruari)

3. Musrembang kabupaten/kota (dilaksanakan pada bulan maret).

Tugas pemerintahan desa/ kelurahan dalam menyusun perencanaan

pembangunan Desa/ kelurahan adalah melaksanakan musyawarah Perencanaan pembangunan Desa/kelurahan (Musrembang Desa/kelurahan) dengan melibatkan secara aktif seluruh masyarakat desa secara benar. Tujuan Musrembang Desa / kelurahan antara lain:

1. Menampung aspirasi dan menetapkan prioritas kebutuhan masyarakat yang diperoleh dari musyawarah perencanaan pada tingkat di bawahnya.

2. Menetapkan prioritas kegiatan desa yang akan di biayai melalui alokasi Dana Desa yang berasal dari APBD kabupaten /Kota maupun sumber pendanaan lainnya.

3. Menetapkan prioritas kegiatan yang akan di ajukan untuk dibahas pada musrembang kecamatan.

Kemudian Masukan Musrembang Desa / kelurahan yang dipersiapkan oleh Sekretaris Desa/ kelurahan berupa:

a. Daftar permasalahan desa, seperti peta kerawanan kemiskinan dan pengangguran.

b. Dokumen rencana pembangunan jangka menengah (RPJM) desa/kelurahan.

c. Hasil evaluasi pelaksanaan pembangunan desa/kelurahan tahun sebelumnya.

d. Daftar prioritas masalah di bawah desa/kelurahan dan kelompok - kelompok masayarakat, seperti kelompok petani, nelayan dan sebagainya.

Keluaraan (hasil) musrembang Desa kelurahan adalah dokumen - dokumen yang berisikan:

1. Prioritas kegiatan pembangunan skala desa/kelurahan yang akan di danai oleh alokasi dana desa dan atau swadaya.

2. Prioritas kegiatan pembangunan yang akan dilaksanakan mellui SKPD yang dilengkapi dengan kode desa/kelurahan dan kecamatan dan akan masih dibahas pada forum musrembang kecamatan

3. Berita acara musrembang desa / kelurahan. (hanif Nurkholis, 2008 :97)

Perencanaan pembangunan desa disusun secara partisipatif yaitu melibatkan semua unsur masyarakat desa yang terdiri dari ketua RT/RW, tokoh masyarakat, pemangku adat, ketua organisasi kemasyarakatan, ketua organisasi perempuan, LSM dan lain sebagainya. Prerencanaan pembangunan Desa terdiri dari:

1. Rencana pembangunan jangka menengah desa (RPJM Desa) adalah dokumen perencanaan untuk periode 5 (lima) tahun yang memuat arah dan kebijakan pembangunan desa, arah kebijakan keuangan desa, kebijakan umum, dan program, program perangkat desa, program prioritas kewilayahan, disertai dengan rencana kerja. 
2. Rencana kerja pembangunan desa (RKP Desa). Adalah dokumen perencanaan untuk periode 1 (satu) tahun merupakan penjabaran RPJM- Desa yang memuat rancangan kerangka ekonomi desa, dengan mempertimbangkan kerangka pendanaan yang dimutahirkan, program prioritas pembangunan desa, rencana kerja dan

pendanaan serta prakiraan maju, baik yang dilaksanakan langsung oleh Pemerintah Desa maupun yang ditempuh dengan mendorong partisipasi masyarakat dengan mengacu kepada renacana kerja pemerintahan daerah dan RPJM Desa dan ditetapkan dalam keputusan desa dengan berpedoman pada peraturan Daerah.

Penyusunan perencanaan pembangunan desa harus di dasarkan pada data dan informasi yang akurat dan dapat dipertanggung jawabkan. Data dan informasi yang diperlukan dalam penyusunan perencanaan pembangunan desa mencakup:

a. Penyelenggaraan pemerintahan Desa.

b. Organisasi dan tata laksana pemerintahan desa.

c. Keuangan desa

d. Profil desa

e. Informasi lain terkait dengan penyelenggaraan pemerintahan desa dan pemberdayaan masyarakat. (Nurcholis,2011:108).

\section{METODE}

Penelitian dilaksanakan di kecamatan Tambang kabupaten Kampar Provinsi Riau dengan mengambil sampel beberapa desa yaitu mengamati dan memetahkan rencana, program dan kegiatan pembangunan Desa, baik yang sedang berjalan maupun yang akan diusulkan oleh masyarakat desa melalui forum Musyawarah Rencana Pembangunan Desa (musrembandes). Dan penetapan prioritas pembangunan. Adapun desa sampel yang ditetapkan yaitu Desa Tarai bangun, Desa Rimbo panjang dan desa Tambang kecamatan tambang kabupaten Kampar. Pendekatan penelitian yang dilakukan dengan pemetaan sosial dan pendekatan Participatory rural appraisal (PRA) yaitu pendekatan dan teknik teknik perlibatan masyarakat dalam proses - proses pemikiran yang berlansung selama kegiatan perencanaan dan pelaksanaan, serta pemantauan dan evaluasi program pembangunan masyarakat (Driyamedia,1996).

\section{HASIL DAN PEMBAHASAN}

Pemetaan data dan informasi penyusunan perencanaan pembangunan desa di kecamatan Tambang kabupaten Kampar dengan menetapkan tiga desa sampel yaitu Desa Tarai Bangun, Desa Rimbo Panjang dan Desa Tambang. Pemetaan data dan informasi yang dilakukan menyagkut pada 5 aspek yaitu :

1. Penyelenggaraan pemerintahan Desa.

2. Organisasi dan tata laksana pemerintahan desa.

3. Keuangan desa

4. Profil desa

5. Informasi lain terkait dengan penyelenggaraan pemerintahan desa dan pemberdayaan masyarakat.

Dari 5 (lima) aspek pemetaan kegiatan pendataan merupakan serangkaian pemerolehan data dan informasi yang dijadikan bahan untuk melaksanakan kegiatan penyusunan perencanaan pembangunan desa. Ketersediaan data maupun informasi dapat membantu pemerintahan desa dalam merumuskan 
kegiatan pembangunan pada saat kegiatan Musyawarah Perencanaan Pembangunan Desa atau disebut dengan (Musrembang Desa). Musrembang dapat efektif terlaksana bila kondisi desa dan permasalahan desa dapat dipahami secara bersama - sama oleh pemerintah dan masyarakat desa. Pemahaman yang dimaksud adalah kemampuan pemerintahan desa dan masyarakatnya untuk menggali secara mendalam pembuatan dan perumusan perencanaan pembangunan desa dan penetapan prioritas pembangunan desa yang akan didanai dalam kegiatan pembangunan pedesaan bersumber dari Alokasi dana desa maupun dari APBD kabupaten/kota.

Kemampuan aparatur Pemerintahan desa dalam menyelenggarakan Pemerintahan, pembangunan, pelayanan dan pemberdayaan kepada masyarakat desa memberikan kemudahan bagi desa untuk merumuskan dan menetapkan rencana program dan kegiatan yang di inginkan oleh desa setempat. Untuk itu data dan informasi yang digunakan dalam pembuatan penyusunan perencanaan pembangunan desa menjadi kebutuhan mendasar untuk merumuskan dan menetapkan pembangunan desa.

Dari penelitian yang dilaksanakan di tiga desa sampel yang menyoroti permasalahan tentang data dan informasi yang seharusya di miliki oleh Desa dalam pembuatan atau penyusunan perencanaan pembangunan desa terlihat masih kurangnya kemampuan aparatur dalam memahami pembuatan penyusunan perencanaan pembangunan desa yang dikaitkan dengan kebutuhan data dan informasi sebagai pendukung dalam kegiatan musrembang desa yang di inginkan.

Dampak dari kurangnya pemahaman aparatur desa dan kurang tersedianya data dan informasi yang tersedia menyebabkan kurang efektifnya pelaksanaan penyusunan perencanaan desa dan penepatan prioritas pembangunan desa yang dihasilkan dari kegiatan Musyawarah rencana pembagunan desa (musrembangdes) dikecamatan Tambang Kabupaten Kampar.

Penyusunan perencanaan pembangunan desa merupakan kegiatan penting untuk terlaksananya musyawarah rencana pembangunan desa (Musrembangdes). Luaran atau hasil dari musrembang desa adalah penetapan prioritas pembangunan desa. Oleh karena itu kegiatan penyusunan perencanaan desa memerlukan serangkaian data dan informasi yang dibutuhkan sebagai prasyarat penyelenggaraan musrembang ditingkat Desa.

Desa tarai bangun, Desa Rimbo panjang dan Desa Tambang kecamatan Tambang Kabupaten Kampar melaksanakan MusrembangDes setiap tahunnya yaitu pada bulan Januari, bulan pebruari dikecamatan dan bulan maret adalah musrembang kabupaten/ kota terwujudnya musrembang desa tergantung pada kemampuan aparatur desa dalam menyusun perencanaan desa yang didukung dengan tersedianya data dan informasi yang saling mendukung dalam proses perencanaan pembangunan pedesaan.

Berdasarkan hasil penelitian tentang pemetaan data dan informasi perencanaan pembangunan desa dapat dijelaskan sebagai berikut:

\section{Penyelenggaraan Pemerintahan desa.}

Penyelengaraan pemerintahan desa adalah kegiatan organisasi pemerintahan desa dalam menyelenggarakan kegiatan bidang Pemerintahan, bidang Pembangunan, bidang soial dan bidang pemberdayaan kepada masyarakat. Keseluruhan bidang - bidang tersebut menggambarkan tugas dan fungsi pemerintahan Desa yang diselenggarakan oleh kepala desa dengan perangkatnya. Sehubungan dengan itu dapat dipetakan keadaan penyelenggaraan Pemerintahan desa di tiga sampel (Desa tarai bangun, Desa Rimbo Panjang dan Desa Tambang)

Dari data didapat dijelaskan bahwa data dan informasi yang berkaitan dengan penyelenggaraan Pemerintahan Desa di Tiga Desa, terlihat bahwa Desa Rimbo Panjang, dimana aktivitas pemerintahan, pembangunan, social dan pemberdayaan kepada masyarakat dikategorikan masih rendah. Hal ini diketahui dari proses Penyusunan perencanaan pembangunan Desa kurang memperhatikan aspek penyelenggaraan fungsi - fungsi pembangunan, social pedesaan, dan pemberdayaan masyarakat. Sehingga penyusunan perencanaan pembangunan desa yang harus di dukung dengan penguatan fungsi 
penyelenggaraan pemerintahan Desa masih kurang dapat mendukung terhadap penyusunan perencanaan Pembangunan Desa yang di tetapkan.

\section{Organisasi dan Tata Laksana Desa.}

Organisasi dan tatalaksana desa merupakan kemampuan sumberdaya organisasi dan sumber daya manusia dalam menyelenggarakan tugas pokok dan fungsi Pemerintahan Desa yang efektif dan efisien. Data dan informasi mengenai organisasi dan tatalaksana desa dijadikan bahan dan informasi untuk memperkuat penyusunan perencanaan pembangunan desa. Penyusunan perencanaan Pembangunan desa yang lengkap dapat dijadikan masukan dalam kegiatan Musyawarah rencana pembangunan desa. Ketersedian data dan informasi organisasi tatalaksana desa mencakup pada aspek tata kelola manajemen Desa sarana dan prasarana, SDM aparatur. Sehubungan dengan itu gambaran organisasi dan tatalaksana desa pada tiga desa sampel

Dari data didapat dijelaskan data dan informasi organisasi tatalaksana tiga desa yaitu Desa tarai bangun, Desa Rimbo Panjang dan Desa Tambang. Data dan informasi yang digunakan untuk penyusunan perencanaan pembangunan desa mencakup tatakelola manajemen, sarana dan prasarana desa dan SDM aparatur pemerintahan Desa. Pada data di atas disebutkan bahwa Rimbo panjang dan Desa Tambang menunjukan tatakelola manajemen desa kurang terampil, sarana dan prasarana desa yang masih kurang tersedia, serta kemampuan SDM aparatur atau perangkat desa yang masih terbatas.hal ini dapat disimpulkan masih rendahnya atau kurang lengkapnya ketersediaan data organisasi dan tatalaksana desa dalam penyusunan perencanaan pembangunan desa, sehingga penyusunan perencanaan kurang efektif dapat dilaksanakan di dua desa tersebut.

\section{Kuangan Desa.}

Keuangan desa merupakan segala sumber pendapatan desa yang dapat dikelola oleh Pemerintahan Desa dan dijadikan sumber biaya kegiatan pembangunan dan peningkatan kesejahteraan masyarakat Desa. Sumber keuangan Desa di peroleh dari Pendapatan asli desa (PAD), Alokasi Dana dan Desa (ADD), maupun bantuan dari Pemerintah Provinsi dam Kabupaten/kota diseluruh Indonesia. Pengelolaan keuangan desa yang dilaksanakan oleh petugas keuangan dengan Desa memliki pengetahuan dan keahlian yang terampil dalam akuntansi keuangan desa.

Dari data didapat dijelaskan keadaan keuangan desa dari tiga obyek Desa penelitian menunjukan pengelolaan keuangan desa bersumber dari Pendapatan Asli Desa (PAD), Alokasi Dana Desa dan Bantuan Pemerintah Provinsi dan Kabupaten/Kota, dimana Desa Rimbo Panjang dan Desa Tambang keadaan keadaan keuangan desa dikategorikan kurang terkelolah. Keadaan demikian menggambarkan sumber Pendapatan Desa seharusnya dapat dijadikan acuan data yang tersedia untuk pembuatan penyusunan perencanaan pembangunan desa. Sumber anggaran pendapatan yang kurang terkelolaa menjadi factor penghambat dalam penyusunan perencanaan desa secara baik.

Mengenai kondisi keuangan Desa di Desa Tarai bangun dimana fungsi - fungsi keuangan pada pengelolaan sumber - sumber keuangan pendapatan desa dikategorikan cukup mendukung dalam pengelolaan keuangan desa secara akuntabel. Terkelolanya keuangan desa secara akuntabel tentunya akan memberikan kemudahan dalam penyusunan perencanaan pembangunan desa yang dibahas pada Musyawarah Rencana Pembangunan Desa dan dapat dijadikan penetapan perioritas pembangunan dengan anggaran Biaya pembangunan yang tersedia.

\section{Profil Desa.}

Profil desa merupakan gambaran umum desa yang menjelaskan kondisi desa secara keseluruhan. Profil Desa berisikan tentang Data keluarga, data potensi desa dan data perkembangan desa.Keseluruhan data yang tersedia dapat dijadikan bahan dan masukan desa dalam pelaksanaan musyawarah rencana pembangunan desa yang di lihat dari ketersediaan Profil sebagai pendukung pembuatan penyusunan perencanaan pembangunan desa. 
Dari data di dapat dijelaskan profil Desa yang dijadikan data dan informasi penyusunan perencanaan pembangunan desa, dimana dari tiga Desa sampel menunjukan Desa Rimbo panjang keadaan profil desa belum didukung dengan profil desa yang lengkap. Keadaan demikian memberikan dampak yang kurang optimal dalam pembuatan penyusunan perencanaan desa. Begitu juga dengan Desa Tambang ketersedian data perkembangan desa kurang tersusun, sehingga maju atau mundurnya perkembangan pembangunan desa belum dapat terukur oleh Pemerintah Desa Tambang.

Lainnya halnya Desa Tarai bangun bahwa profil Desa telah tersedia dengan adanya data keluarga, data potensi Desa dan data perkembangan desa yang dapat menggambarkan keadaan desa secara keseluruhan, namun masih ada kekurangan dalam membuat profil desa secara baik. Dengan demikian dapat disinpulkan bahwa profil desa yang lengkap dan tersedia akan memudahkan pembuatan penyusunan perencanaan pembangunan desa yang pada tahap selanjutnya dapat dijadikan bahan dalam kegiatan Musyawarah Perencanaan pembangunan Desa (musrembanhgDesa).

\section{Informasi Pemerintahan Dan Pemberdayaan Masyarakat.}

Informasi pemerintahan Desa dan Pemberdayaan Masyarakat dijadikan data Pendukung dalam pembuatan penyusunan perencanaan Pembangunan Desa. Tersedianya data informasi pemerintahan dan kegiatan pemberdayaan kepada masyarakat dapat memberikan kemudahan kepada warga dalam mendapatkan segala bentuk layanan yang disediakan oleh Pemerintahan Desa. Data dan informasi yang disediakan oleh Pemerintah Desa berupa: media informasi yang tersedia baik secara lisan mapun tulisan (papan Pengumuman) serta media informasi secara mendia online.

Sehubungan dengan hal di atas, pentingnya data dan informasi pemerintahan maupun pemberdayaan masyarakat yang diselenggarakan oleh Pemerintah Desa akan sangat membantu warga dan masyarakat luas untuk mengetahui keterangan/ berita baik secara langsung mapun tidak langsung diperoleh oleh warga sebagai pengguna jasa informasi yang di inginkan. Untuk mengetahui kondisi Data informasi Pemerintahan dan Pemberdayaan Desa di tiga desa sampel penelitian.

Dari data di dapat dijelaskan data informasi pemerintahan dan pemberdayaan masyarakat yang terseedia di tiga desa sampel penelitian, menunjukan bahwa hampir keseluruhan desa tidak memiliki sarana informasi komonikasi yang tersedia. media online yang belum memiliki data Home Base desa, papan pengumuman belum mencakup keseluruhan informasi yang dibutuhkan masyarakat, dan kontok person hanya digunakan pengguna pribadi dari masing - masing aparatur kepada masyarakat dalam memberikan informasi yang di buthkan.

Dari hal tersebut, data dan informasi yang tersedia akan dapat memberikan kemudahan untuk desa dalam menyusun perencanaan pembangunan dengan baik. Pentingnya ketersediaan media informasi tidak hanya untuk melakukan hubungan antara penyelenggara dengan masyarakat (warga), tetapi yang lebih penting lagi kemudahan bagi desa untuk merancang perencanaan pembangunan sesuai dengan data dan informasi yang lengkap, akurat dan dapat dipertanggung jawabkan dalam memenuhi pelayanan publik di pedesaan.

\section{1) Faktor-Faktor penghambat dalam penyusunan perencanaan pembangunan desa di kecamatan tambang Kabupaten Kampar.}

Penyusunan perencanaan pembangunan desa merupakan kegiatan untuk mengumpulkan segala bahan dan dokumen yang dibutuhkan dalam penyusunan perencanan pembangunan desa dan penetapan prioritas pembangunan Desa yang dihasilkan dari Musrembang Desa tahunan. Data dan informasi yang tersedia dijadikan bahan - bahan kelengkapan dalam merencanakan dan melaksanakan pembangunan desa. Kegiatan penyusunan perencanaan pembangunan desa dikecamatan Tambang Kabupaten Kampar kurang efektif terselenggara disebabkan factor - factor sebagai berikut :

a. Desa tidak memiliki profil desa yang lengkap.

b. Sumber potensi desa belum dapat dikembangkan. 
c. Sumber daya aparatur desa yang belum memahami dalam pembuatan perencanaan desa, baik dalam pembuatan RPJMD dan RKP Desa.

d. Sistem informasi Desa (simdes) yang belum tersedia.

Berdasarkan hal tersebut di atas penyusunan perencanaan pembangunan desa di kecamatan Tambang kabupaten Kampar belum efektif terlaksana, sehingga kegiatan musrembangdesa dan penetapan prioritas pembangunan desa belum sesuai dengan kebutuhan dan aspirasi masyarakat desa.

\section{KESIMPULAN}

Dari hasil penelitian tentang Pemetaan data dan informasi penyusunan Perencanaan Pembangunan Desa di kecamatan Tambang Kabupaten Kampar dapat disimpulkan hasil penelitian sebagai berikut :

1. Hasil penelitian menyebutkan bahwa ketiga desa sampel penelitian dalam penyediaan data dan informasi yang digunakan dalam penyusunan perencanaan pembangunan desa dapat dikategorikan kurang lengkap.

2. Penyusunan Perencanaan Pembangunan Desa kurang efektif dikarenakan RPJMDesa belum tersusun, sehingga RKP Desa kurang maksimal terlaksana.

3. Factor penghabat penyusunan perencanaan desa yaitu SDM masih lemah, profil desa kurang tersedia dan potensi desa belum dapat dikembangkan.

\section{DAFTAR PUSTAKA}

[1]. Hanif Nurcholis, 2011, pertumbuhan dan penyelenggaraan Pemerintahan Desa, Air langga Jakarta

[2]. Hanif Nurcholis 2008, perencanaan partisipatif Pemerintahan daerah, Grasindo, Jakarta.

[3]. Jhon Creswel, 2010, Reserach Design, Pustaka Pelajar Yogyakarta.

[4]. K.Suhendra, 2011, Peran birokrasi dalam pemberdayaan Masyarakat, Alphabeta Bandung.

[5]. Riant Nugroho, 2011, Manajemen perencanaan pembangunan, Gramedia Jakarta.

[6]. UU.No.6 tahun 2014 tentang Desa, Rona Publishing, Surabaya.

[7]. Peraturan Pelaksana Pemerintahan daerah, 2006, Eko Jaya Jakarta.

[8] Himpunan Petunjuk pelaksanaan Desa / kelurahan, 2008, fokusindo, Bandung.

[9]. Rancangan Awal RPJMD Propinsi Riau 2014 - 2019, Pekanbaru, Bappeda Propinsi Riau, Pekanbaru 